\title{
Picture Book: Its Effect on EFL Reading Comprehension
}

\author{
$1^{\text {st }} \mathrm{O}$ Wardini \\ English Education Study Program, \\ Faculty of Psychology and Education \\ Universitas Muhammadiyah Sidoarjo \\ Jl. Mojopahit 666B, Sidoarjo, East \\ Java, Indonesia \\ fikamegawati@umsida.ac.id
}

\author{
$2^{\text {nd }} F$ Megawati \\ English Department, Faculty of Letters \\ Universitas Negeri Malang \\ Jl. Cakrawala No.5, Sumbersari, Kec. \\ Lowokwaru, Kota Malang, Jawa Timur \\ 65145
}

\author{
$3^{\text {rd }}$ Y Astutik \\ English Education Study Program \\ Faculty of Psychology and Education \\ Universitas Muhammadivah Sidoarjo \\ Jl. Mojopahit 666B, Sidoarjo, East \\ Java, Indonesia
}

\begin{abstract}
Selecting instructional media is a prominent aspect in classroom activities. Combining pictures and text is considered effective for teaching and learning foreign language. Accordingly, picture books are meaningful media that use integration of words, illustration, and design. In the context of language learning, teachers need to be selective of using or making picture books in term of shape, content, and genre of the text. Focusing on the genre, narrative text plays an important role in school curriculum since local culture can be inserted to build students' cultural awareness. Regarding the gap showing few studies given more attention on teacher made picture book for reading skill, this paper investigates the effect of picture books toward student's English reading comprehension. Pre-experimental design was carried out, and this study involved thirty-five secondary school students as sample, especially the tenth graders. The instrument of this study were tests. The tests were constructed and tried them out to produce valid items. The data were analyzed by using $t$ test after the fulfillment of statistical assumption was checked. For the media, they were validated by two experts before implementation. The result shows that there is a significant effect of using picture books to students' ability in understanding narrative texts more comprehensively.
\end{abstract}

\section{Keywords-Picture book, EFL, Reading}

\section{INTRODUCTION}

Teaching reading is an activity performed to make the students able to understand text and interpret the information appropriately. When the context used is for EFL learners, introducing effective way to read is one of the pivotal tasks for the teachers since more efforts are needed to assist them grasp meaning with their native language concept. Limited exposure of reading activities seems to be the contributing factors of this issue. The exposure itself can be influenced by various aspects such as age and years [1]. Such lack of exposure tend to cause low motivation in reading. As a result, they consider reading class is not easy including high school students [2]. The issue of EFL reading is still an interesting area to explore. In this case, teaching reading needs innovation that make students eager to read which in the end they can improve their reading skills in English. Accordingly, this topic attracts [3] to investigate how to build students' reading habit through School Literacy Movement program. Besides, from the view of student skill development, [4] have found one interesting way to make reading class more interesting through promoting student-generated comics from the literature the students have read. Thus, to make the learners engaged to the reading classroom and to encourage them to be a strategic reader, teacher's innovation to give more experiences plays important role to be explored [5].

One of the interesting media that can be used in teaching reading is picture book. Picture book provides students with resources for language exploring. The combination of pictures and texts are suitable to arouse students' capability in reading. According to [6], picture book are bringing a storyteller in the class to act as a guide for the experiences. The stories have the most powerful way in teaching. Picture book is powerful in various ages because the themes are deal of them. Therefore, using picture book to teach tenth graders of senior high school narrative text is also appropriate. Reading narrative text about legend is one of language skills that the tenth grade students should be mastery because it was writing in syllabus which is on basic competence for second semester number 3.8 and 4.8 .

One great idea taken form picture book is its function for presenting local culture as the materials for the students in reading class as studied by [7, 8]. However, not many teachers have spent their time to generate their own picture book. Adopting the existing materials seems to be the easy way to apply, while adapting or creating materials or media is highly recommended to give appropriate inputs. Considering the importance of bringing local culture to teach foreign language through media and the studies discussing picture book showing its power to assist students' learning not only for children but also all ages [9, 10], this study would like to investigate whether there is any effect of using picture book to the students' reading comprehension, particularly in Narrative Text in the form of legends in the secondary school level students. The research question is formulated as follows: Is there any effect of using picture 
book towards students' reading comprehension in narrative text?

\section{METHODS}

This study used pre-experimental design or one-group pretest-posttest design. The researcher selected X-IPS2 among six classes in one of private senior high schools in Sidoarjo, Indonesia as the sample of this study. The process took place around one month, mid until the end of April 2019. To collect the data, reading comprehension question in the form of objective test was used. The indicators used were emphasized on reading looking for main idea and moral value. Before the tests were given, it was tried out to a class of different students. The items given when try-out consisted of 32 questions. After the items had been triedout, the result of the students' answers were calculated with the validity test and reliability test. The result of the questions which were valid and reliable were selected to pre-test and post-test. Accordingly, 20 questions with high level of validity percentage criterion and appropriate with indicator in lesson plan were used for the tests.

In addition to checking the validity of lesson plan and worksheet before they were used in the treatment, dealing with teacher-generated picture book as the media, some steps were also conducted in order to provide eligible media First, narrative texts in the form of legends were selected. As a result, there were two titles appropriate with the students' level and curriculum. Second, selecting pictures was carried out with some consideration, namely clarity and relevance. Third, inserting text to construct the story was composed through modifying the existing texts to make it more comprehensive for the students. Selecting the appropriate layout to combine text and picture was also an important thing to do. Then when the picture book was ready in printed version, it was validated by two experts in teaching media to check the eligibility of the English text and picture combination from the very first page until the last one. There were some revision on the English text before it was ready to be used as media in teaching narrative text. The summary of this procedure is depicted in Figure 1. To know the validity of three components of this study evaluated from two experts, Table 1 presents the process of the construction.

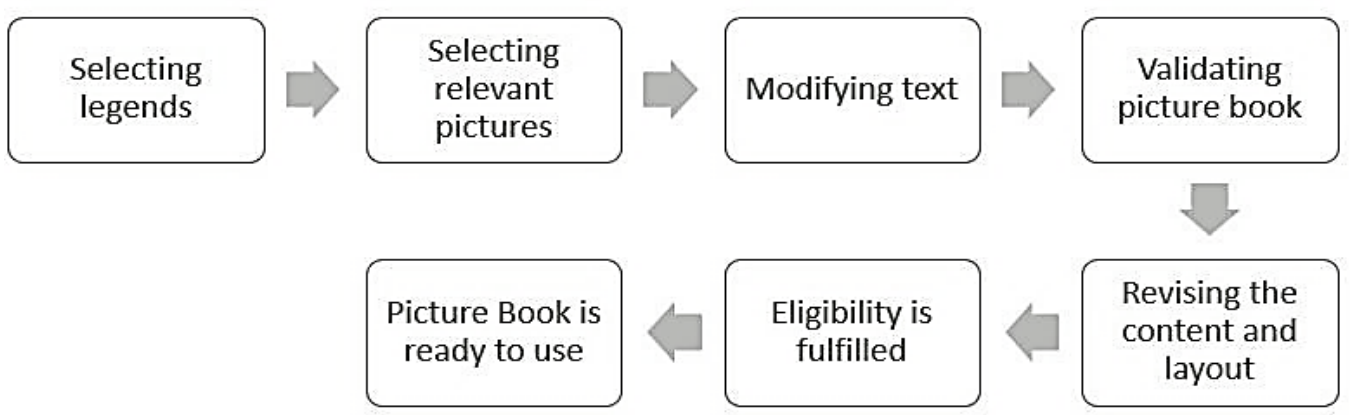

Fig 1. Procedure of picture book construction

TABLE I. THE RESULT OF VALIDATION SHEET SCORE

\begin{tabular}{|l|c|c|c|c|}
\hline \multicolumn{1}{|c|}{ Instrument } & Validator I & Validator II & Percentage & Validity Level \\
\hline Lesson Plan & 56 & 59 & $89.80 \%$ & Very Valid \\
\hline Picture Book & 36 & 37 & $91 \%$ & Very Valid \\
\hline Students' Worksheet & 48 & 50 & $87.50 \%$ & Very Valid \\
\hline
\end{tabular}

The next crucial activity was giving treatment by using picture book. The picture book and its worksheet was giving after the students had been given pre-test. Firstly, the researcher gave them the explanation about narrative text summarized in Microsoft power point such as the meaning of narrative text, the general structure of narrative text, the tenses used in narrative text, kinds of narrative text, how got the information from text: main idea and moral value, and gave the example of legend story to make them understood easily. The duration to explain about narrative text was 20 minutes, and 10 minutes for students' opportunity to ask if there was still some points they did not understand. According to [11], there are three initial steps, four main steps and two post steps in reading narrative activities using picture book, but this study did not apply the last one (see Table 2) due to time constraint.

After the explanation of narrative text had been done, picture book and its worksheet were given to students to know the students' reading comprehension in narrative text. Picture books given to the students were entitled "Malin Kundang" and "The Story of Toba Lake" (see Figure 2). Each of picture book had 10 questions, and the duration to read each Picture Book and did the questions was 20 minutes. The students had to alternate with their partner after 20 minutes, so the total of time was 40 minutes. 

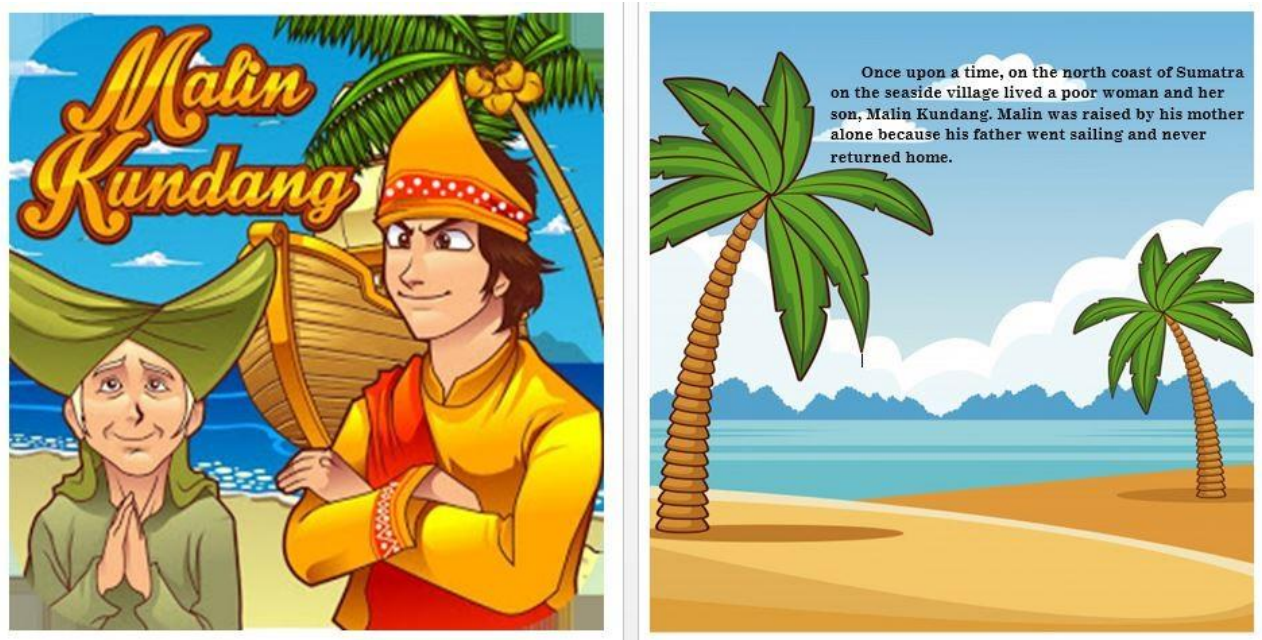

Fig. 2. A part of picture book entitled Malin Kundang

There are some stages to analyze the data, namely, scoring/assessment, normality test, homogeneity test, and hypothesis test. Every students' answer of pre-test and post-test got 1 point. For normality test, Liliefors (Lo) with $\alpha=5 \%$ was applied. The homogeneity test of this research was Variant test (F-test). Having known that the data had fulfilled the requirement of statistical hypothesis, t-test was used.

\section{RESULTS AND DISCUSSION}

The students' score have improved significantly. The result of students' pre-test score, there were 3 students got standard score that the predicate $(\mathrm{C})$ and the statement (Enough). Then 32 students got under minimal score that the predicate (D) and the statement (Less). Furthermore, all the students got good score in post-test that 14 students' score in predicate (A) which the statement was (Very Good) and 21 students' score in predicate (B) which the statement was (Good). The mean score of students' pre-test was 71.57 and the mean score of students' post- test was 90.57. It means that the students gained significant improvement in their score after taught by using picture books.

TABLE II. TEACHING SCENARIO IN IMPLEMENTING PICTURE BOOK ADAPTED FROM [11]

\begin{tabular}{|c|c|c|c|c|}
\hline Steps & Teacher's Activitites & Student's Activities & Renstanto & This Study \\
\hline 1. $\quad$ Initial Step & \multirow{6}{*}{$\begin{array}{l}\text { Teacher models types of } \\
\text { questions to stu- } \\
\text { dents that need while } \\
\text { reading. }\end{array}$} & \multirow{6}{*}{$\begin{array}{l}\text { Students make } \\
\text { the correct ques- } \\
\text { tions and asking } \\
\text { themselves about } \\
\text { The significant } \\
\text { information of the } \\
\text { story. }\end{array}$} & $\mathrm{v}$ & $\mathrm{v}$ \\
\hline & & & & \\
\hline & & & & \\
\hline & & & & \\
\hline & & & & \\
\hline & & & & \\
\hline & \multirow{5}{*}{$\begin{array}{l}\text { Teacher directs stu- } \\
\text { dents for asking some } \\
\text { questions to make } \\
\text { them understand } \\
\text { story better. }\end{array}$} & \multirow{5}{*}{$\begin{array}{l}\text { Students are able } \\
\text { to ask themselves } \\
\text { to find the infor- } \\
\text { mation such as } \\
\text { main idea and } \\
\text { moral value. }\end{array}$} & $\mathrm{v}$ & $\mathrm{v}$ \\
\hline & & & & \\
\hline & & & & \\
\hline & & & & \\
\hline & & & & \\
\hline \multirow[t]{11}{*}{ 2. $\quad$ Main Steps } & Teacher provides ex- & Students capable & $\mathrm{v}$ & $\mathrm{v}$ \\
\hline & plicit teaching to stu- & creating mental & & \\
\hline & dents while they cre- & Images of story & & \\
\hline & ate mental images & as they compre- & & \\
\hline & with assistance of il- & Hend procedure & & \\
\hline & lustrations & through reading & & \\
\hline & Teacher guides stu- & Students guessing & $\mathrm{v}$ & $\mathrm{v}$ \\
\hline & dents predicting the & and reviewing the & & \\
\hline & story based on the & story such as what & & \\
\hline & stories' structure & is going occur and & & \\
\hline & and students' prior & the author's ideas. & & \\
\hline
\end{tabular}




\begin{tabular}{|c|c|c|c|c|}
\hline Steps & Teacher's Activitites & Student's Activities & Renstanto & This Study \\
\hline & knowledge & & & \\
\hline & Teacher gives in- & Students associate & $\mathrm{v}$ & $\mathrm{v}$ \\
\hline & structions for stu- & the pictures and & & \\
\hline & dents to look at the & the story work to- & & \\
\hline & Illustrations (pic- & gether. & & \\
\hline & tures or characters) & & & \\
\hline & to comprehend the & & & \\
\hline & story better & & & \\
\hline & Teacher guides stu- & The students & $\mathrm{v}$ & $\mathrm{v}$ \\
\hline & dents comprehend & make conclusions & & \\
\hline & the story by way of & that combined & & \\
\hline & looking at context & With another & & \\
\hline & when they find the & Information or & & \\
\hline & difficult words: & their background & & \\
\hline & & knowledge & & \\
\hline 3. $\quad$ Post Steps & Teacher asks the stu- & Students discuss & $\mathrm{v}$ & $\mathrm{x}$ \\
\hline & dents to discuss and & and summarize & & \\
\hline & summarize the story & The story and & & \\
\hline & and summarize the & Summarize the & & \\
\hline & story. & story. & & \\
\hline
\end{tabular}

Further, the analysis result show that $\mathrm{t}_{\text {count }}$ was 19.412 and $\mathrm{t}_{\text {table }}$ with $\alpha=0.05$ and $\mathrm{df}=34$ was 1.691 . It can be concluded $\mathrm{t}_{\text {count }}>\mathrm{t}_{\text {table }}=19.412>1.691$. The result indicated the null hypothesis that there is no effect of picture book towards students' reading comprehension in narrative text was rejected. It means that picture book as the medium that used in reading class was effective to students' reading comprehension in narrative text.

The finding of this study indicating the effect of using picture book for teaching supports previous research [1214]. Besides, the students who were treated with picture book were more active and easy to understand the stories because the presence of pictures encourages students to know the meaning of the text. In reading activity, students' brain is active analyzing and comparing the visualization of pictures and text.

Generating picture book is a practice for teachers to develop their creativity in matching the media and students' needs more interestingly. This activity needs sense of art to produce a beautiful layout to attract the students' attention and engagement. Picture book is a book in which the story depends on the relation of text and pictures that both have been created with a conscious aesthetic intention. According to [15], picture book is a book consisting of pictures and text and they are blended in creating a whole artistic of stories' meaning. Moreover, the more interested students in involving themselves can motivate them to comprehend what they read. [16] states that picture book is a book which helps the readers understand the stories through observing the illustrations that are present to increase the value of written words. With the skill of generating picture book for the purpose of English learning, teachers can be a model for learners to help them create their literacy source based on their own concept as promoted by [17].

Related to the step of teaching, this study showed that implementing two out of three steps of teaching using picture book (initial steps and main steps) promoted by [11] can be applied. This means that situation of the class determines how the researchers took action in classroom activities. Another important specific part in picture book construction is translation accuracy and cultural relevance [18]. This issue is a sensitive case since it deals with one community's custom. When the legend is popular, it is easier to check from many sources. In contrast, if the legend is not quite well-known, there should be multiple check to avoid misinformation.

\section{CONCLUSION}

In a nutshell, the researchers conclude that using picture book as a medium in teaching and learning reading is effective to improve students' reading comprehension in narrative text. The appropriate media can give motivation to students in improving their learning to read. Regarding the limitation of this study related to the small sample, teaching stages, and the form of picture book, next researchers were recommended to investigate further development of picture books for enhancing not only English reading skill, but also other potential skills like speaking and writing. Additionally, this study implies that creativity to insert local culture into the materials or media should be given more attention in order to build students' cultural awareness. To get more inputs, evaluation to the available picture book can be prominent issue to provide better quality of the media. In order to raise students' creativity, involving students' participation in designing and producing picture book is a good project to be investigated. For teacher education institution, holding a workshop 
focusing on helping student create their own book is one of inspiring idea for teacher professional development program.

\section{ACKNOWLEDGMENTS}

We thank Universitas Muhammadiyah Sidoarjo for the support and chance to publish this article in PVJ- isHESSH 2020. For the reviewers, we thank the anonymous referees for the useful suggestions.

\section{REFERENCES}

[1] J. Fitzgerald, A. J. Stenner, E. E. Sanford-Moore, H. Koons, K. Bowen, and K. H. Kim, "The relationship of korean students' age and years of English-as-a-Foreign-Language exposure with English-reading ability: A cross-age Study," Read. Psychol., vol. 36, no. 2, pp. 173-202, 2015. [Online]. Available: 10.1080/02702711.2013.843063; https://dx.doi.org/10.1080/027 02711.2013 .843063

[2] S. Sabnawati, "The effect of picture story book toward reading comprehension and reading motivation of the second graders of SMPN-8 Palangka Raya," 2018. [Online]. Available: http: //digilib.iain-palangkaraya.ac.id/1629/

[3] F. Megawati and F. Wulandari, "Promoting big book and reading corner to support gerakan literasi sekolah (GLS) in primary school," in Seminar Nasional Pendidikan: Tema "Desain Pembelajaran di Era Asean Economic Community (AEC) untuk Pendidikan Indonesia Berkemajuan," 2017.

[4] D. Novita and S. Setiawan, "Bringing student-generated comic as a collaborative project into the extensive reading program," JEES (J. English Educ. Soc), vol. 5, no. 1, pp. 39-46, 2020. [Online].

Available: https://journal.umsida.ac.id/index.php/jees/article/view/366

[5] M. Perkins, "Student teachers' perceptions of reading and the teaching of reading: The implications for teacher education," Eur. J. Teach. Educ., vol. 36, pp. 293-306, 2013. [Online]. Available:

https://www.tandfonline.com/doi/abs/10.1080/02619768.2013.7 63790

[6] D. Kriesberg, "A sense of place: Teaching children about the environment with picture books," Ed. Colorado: A Division of Libraries Unlimited, Inc, 1999.

[7] J. Ilogho, "The role of picture books in promoting reading culture among Nigerian children: Implication for libraries and development of leadership qualities," Int. J. Acad. Libr. Inf. Sci., vol. 3, pp. 66-71, 2015.

[8] S. M. Murni, and M. Solin, "Local culture literacy movement: Empowering students' mother tongues to promote cognitive and affective development in the primary schools," Int. J. Lang. Lit. Linguist. vol.4, no. 2, pp. 65-70, 2018. [Online]. Available: 10.18178/ijll1.2018.4.2.152;https://dx.doi.org/10.18178/ijll1.201 8.4.2.152

[9] C. Giorgis, "The power of reading picture books aloud to secondary students," Clear. House., vol. 73, no. 1, pp. 51-53, $1999 . \quad$ [Online]. Available: https://dx.doi.org/10.1080/00098659909599640

[10] L. Unsworth and M. Macken-horarik, "Interpretive responses to images in picture books by primary and secondary school students: exploring curriculum expectations of a 'visual grammatics,", pp. 56-79, 2015. [Online]. Available: 10.1111/eie.12047;https://dx.doi.org/10.1111/ eie.12047

[11] M. Restanto, "The use of picture book in teaching reading for junior high school students," J. English Educ., vol. 4, no. 2, pp. 49-62, 2016.

[12] R. $\mathrm{Hu}$ and M. Commeyras, "A Case Study: Emergent biliteracy in English and Chinese of a 5-year-old Chinese child with wordless picture books," Read. Psychol., vol. 29, no. 1, pp. 1-30, 2008. [Online]. Available: 10.1080/02702710701260581; https: //dx.doi.org/10.1080/02702710701260581

[13] D. W. Premont, T. A. Young, B. Wilcox, D. Dean, and T. G. Morrison, "Picture books as mentor texts for 10th grade struggling writers," Lit. Res. Instr., vol. 56, no. 4, pp. 290-310, 2017. [Online]. Available:10.1080/19388071.2017.1338803; https: //dx.doi.org/10.1080/19388071.2017.1338803

[14] J. A. Montelongo, R. Durán, and A. C. Hernández, "EnglishSpanish Cognates in Picture Books: Toward a Vocabulary Curriculum for Latino ELLs," Biling. Res. J., vol. 36, no. 2, pp. 244-259, 2013. [Online]. Available: 10.1080/15235882.2013.818074; https: //dx.doi.org/10.1080/15235882.2013.818074

[15] B. Kiefer, C. S. Huck, S. Hepler, and J. Hickman, "Children's literature in the elementary school," $2010 . \quad$ [Online]. Available: https://pdfs.semanticscholar.org/c490/ 5624daf66bfb97de35547878c10f1c4134be.pdf

[16] T. Miller, "The place of picture books in middle-level classrooms," J. Adolesc. Adult Lit., vol. 41, pp. 376-381, 1998.

[17] G. Jacobs, "Helping students create their own books the dialogic way," Beyond Words.., vol.8, pp. 1-9, 2020. https://doi.org/10.33508/bw.v8i1.2354

[18] A. M. Dillon, Z. Hojeij, A. Perkins, and R. Malkawi, "Examining the text quality of English/Arabic dual language children's picture books," Int. J. Biling. Educ. Biling., pp. 1- 14, 2018. [Online]. Available: 10.1080/13670050.2017.1415867; https: //dx.doi.org/10.1080/13670050.2017.1415867 